Pace University

DigitalCommons@Pace

$1-1-1990$

\title{
The Work of a CUNY Law Student: Simulation and the Experiential Learning Process
}

Vanessa Merton

Elisabeth Haub School of Law at Pace University

Follow this and additional works at: https://digitalcommons.pace.edu/lawfaculty

Part of the Legal Education Commons

\section{Recommended Citation}

Vanessa Merton, The Work of a CUNY Law Student: Simulation and the Experiential Learning Process, 37 UCLA L. Rev. 1195 (1990), http://digitalcommons.pace.edu/lawfaculty/164/.

This Article is brought to you for free and open access by the School of Law at DigitalCommons@Pace. It has been accepted for inclusion in Pace Law Faculty Publications by an authorized administrator of DigitalCommons@Pace. For more information, please contact dheller2@law.pace.edu. 
APPENDIX

THE WORK OF A CUNY LAW STUDENT:

Simulation and the EXPeriential Learning Process ${ }^{50}$

\section{By Vanessa Merton}

[T] he work you do as part of a simulation is selectively, but not exactly, the same as what you would do as a lawyer confronted with a comparable problem. By drastically shortening the time frame of the actual process, the simulation allows you to to experience the consequences of your choices relatively quickly: In a simulation, you are asked to assume certain roles, and to engage in a variety of tasks, some in-role and some out-of-role (except for the ubiquitous role of "law student"). The generic set of tasks you are asked to engage in are:

1) planning-identifying your purpose, your options, and making some deliberate choices;

2) doing-carrying out the plan you develop, making the adjustments that seem required in light of your underlying purpose;

3) reflecting-seeking to understand what happened, why it happened, and what and how you are learning about lawyering and yourself as a lawyer.

Then the process starts over, with trying the same or similar task again, keeping in mind what you learned from what you did the first time. That is the essence of experiential learning, which we will ask you to do again and again and what lawyers who are willing to learn from their experience do throughout their careers.

This sequence is the unifying pattern of the many stages of this and future simulations. Each stage is important, but we want to place special emphasis on the planning and reflecting phases of the work we engage in. We do not expect you to, and hope that you will not try to, achieve perfection in your performance of lawyering tasks the first time out-or the second, or the fifteenth. Through the simulation, we do hope that you will be able to develop the selfreflective approach to work that will enable you to continue to learn from the chaotic, largely unstructured, uncontrolled experience of being a lawyer.

50. This memorandum was prepared by Professor Merton for distribution to entering CUNY law students and is on file at the UCLA Law Review office. See supra note 40 and accompanying text. 
We believe that the simulation method offers certain advantages over the two models of legal education that preceded it. One model, the apprenticeship model that prevailed until the last quarter of the last century, involved the supervision of a working lawyer. The other model, sometimes called the Langdellian or case method ... has come to mean reading lots of appellate opinions and in large lecture-type classes discussing the legal principles they illustrate. The focus under the first system was very strongly on doing, learning in almost a rote method by following very carefully the rules or techniques that a supervising lawyer used in his-and then it was his-work, with little attention to the apprentice's developing a sense of generalizable principles or legal theory. The emphasis in the second model, to some extent in reaction to the first, was on thinking, with very little attention to learning how to apply in practice the theory and concepts that were discussed in the class, and no attention at all to the possible disparities between, for example, the facts that the judges writing the appellate opinions chose to include and those that may have actually existed.

Our curriculum incorporates substantial elements of both these models, and seeks to integrate their strengths and minimize their shortcomings. ...

In that connection, lawyers need to learn to take calculated risks. A theme we will return to again and again is the impossibility of achieving perfection in professional work. No matter how carefully we plan, however talented and knowledgeable we are, we will always make mistakes. What simulation offers is the chance to make those mistakes in a protected environment in which the consequences of the mistake is not that a client is injured or a cause is lost, but rather that you learn something about the law and lawyering. Since learning is the goal, the "mistake" or "failure" is translated into success. This is not to suggest that you set out to make mistakes; just that the inevitable mistakes have a different meaning in the simulation context.

Ours is a self-reflective approach to the lawyer's role. We do not want to teach in a way that students simply accept the traditional role axiomatically. We want students to have greater choice about how to integrate who they are as persons with what kind of lawyers they want to be. That is no easy task. Learning to fashion a lawyer's role that expresses who you are and is responsive to the needs of others requires continual reflection on the choices we tend to make reflexively and on the other options available. It requires 
attention not only to what we are doing but to who we are becoming. That task, a central part of the mission of this law school, cannot be approached abstractly. It requires doing and reflecting and learning from doing. The simulation mode is ideal for that end. 